\title{
足関節離断性骨軟骨炎（骨軟骨骨折）の検討
}

\author{
健康保険諫早総合病院 \\ 吉 田 省 二・近 藤 正 行 \\ 真島隆三・谷口龍之
}

\section{Osteochondritis Dissecans (Osteochondral Fracture) of the Talus Review of the Literature and Case Reports}

by

\author{
Shoji Yoshida, Masayuki Kondo, \\ Ryuzo Majima and Tatsuyuki Taniguchi \\ Department of Orthopaedic Surgery, \\ Isahaya Insurance Hospital, Nagasaki, Japan
}

\begin{abstract}
Seven patients with osteochondritis dissecans of the talus and tibia were reviewed for a clinical and radiographical follow up. A history of trauma was present in all lateral lesions and a tibial lesion. Radiographically, the location of the medial lesions tended to be in the posterior one third of the dome and the lateral lesions tended to be in the middle one third of it. Furthermore, lateral lesions tend to get worse more easily than medial lesions. We found that lateral lesions were more associated with trauma and needed more careful treatment than medial lesions. We concluded that conservative treatment should be done for stage 1 and 2 lesions and curretage, drilling and fixation is recommended for stage 3 and 4 lesions. When the loose body is too small to fix, only removing it is Suctable treatment.
\end{abstract}

\section{はじめに}

1922 年, Kappis が距骨の離断性骨軟骨炎を報告し て以来, その原因は外傷説, 家族素因説, 循環不全説 などいろいろ考えられてきた。最近では Berndt and Harty ${ }^{1)}$ 報告以来, 外傷説が主流となってきている. しかし，その原因は外傷のみでは説明困難である.今 回我々は 3 年間に 7 例 8 関節の症例を経験したので, 症例を供覧し病態, 治療につき検討を加えた.

\section{症}

\section{例}

対象症例は, 男性 5 例 5 関節，女性 2 例 3 関節の 7 例 8 関節で, 発生年齢は 12〜 43 才, 平均は 20.4 才で あった (表 1 )。発生部位は足関節面の距骨外側 3 関節, 距骨内側 3 関節, 脛骨天蓋 1 関節, 及び距骨関節面の 外側と脛骨天蓋の両方に病変の存在するもの 1 例であ った。うち 1 例は両側の距骨内側に病変を認めた。過
去に明らかな外傷歴を認めたものは 7 例中 5 例で, 外 側例は全てに外傷歷を認めた。

治療は stage 1 の 1 例にドリリング, stage 2 の 1 例 にギブス固定, stage 3 の 2 例にスクリュー固定, stage 4 の 3 例に骨片摘出術を施行した。

症例 $1: 12$ 才, 男性 Berndt 4 型

主訴: 右足関節痛

中学校入学時より陸上部に所属し,週平均 12 時間の 練習をしていた。特に誘因なく階段昇降時の右足関節 痛が出現した。関節周囲の腫脹, 可動域制限は認めな かった。

$\mathrm{X}$ 線所見：単純 X 線像にて右距骨滑車内側の不整 と遊離骨片を認め, 断層撮影や MRI 像でより明瞭に なった（図一 1，2）。

病巣部は距骨滑車内側後方に存在していた。桖爬後, 小骨片用海綿骨螺子にて固定した. 術後 7 力月の現在, 疼痛はない。 
症例 $2: 43$ 才, 男性 Berndt 1 型

主訴：右足関節痛

ソフトボール中にすべりこみ, 右足関節の内反を強 制された。初診時, 前距腓鞀帯, 踵腓勒帯の圧痛を認 めたが, 単純 X 線像にて異常を認めず, 右足関節捻挫 の診断でギブス固定を施行した．その後受診しなかっ たが， 1 年後に疼痛持続するため再受診した。

$\mathrm{X}$ 線所見：単純 X 線像, 断層撮影, CT 像にて距骨
滑車外側に骨透亮像を認めた（図－3）.

手術時関節軟骨に楩山はなく, きれいに保たれてい た.ドリリングを施行した。 症例 $7: 16$ 才, 女性 Berndt 2 型 $\rightarrow 4$ 型 主訴：右足関節痛

バレーボール中に右足関節の内反を強制され, 近医 にてギブス固定をうけた，その後も疼痛が持続するた め来院した．臨床的には，右足関節の前方引き出しテ

表 1 症例

\begin{tabular}{|c|c|c|c|c|c|c|c|}
\hline 症 例 & 年＼cjkstart齢 & 性 別 & 部 & 位 & Berndt の分類 & 外傷歴 & 治 療 法 \\
\hline 1 & 12 & 男 & 距 骨内 側 & (rt.) & 3 & - & スクリュー固定 \\
\hline 2 & 43 & 男 & 距骨外側 & (rt.) & 1 & + & ドリリング \\
\hline 3 & 16 & 女 & $\begin{array}{l}\text { 距骨内 側 } \\
\text { 距骨内側 }\end{array}$ & $\begin{array}{l}\text { (rt.) } \\
\text { (lt.) }\end{array}$ & 3 & - & スクリュー固定 \\
\hline 4 & 15 & 男 & 距骨外側 & (lt.) & 4 & + & 骨片摘出 \\
\hline 5 & 16 & 男 & $\begin{array}{l}\text { 距骨外側 } \\
\text { 脛 骨 側 }\end{array}$ & $\begin{array}{l}\text { (rt.) } \\
\text { (rt.) }\end{array}$ & 4 & + & 骨片摘出 \\
\hline 6 & 25 & 男 & 脛＼cjkstart骨＼cjkstart側 & (lt.) & 4 & + & 骨片摘出 \\
\hline 7 & 16 & 女 & 距 骨 外 側 & (rt.) & 2 & + & ギブス固定 \\
\hline
\end{tabular}

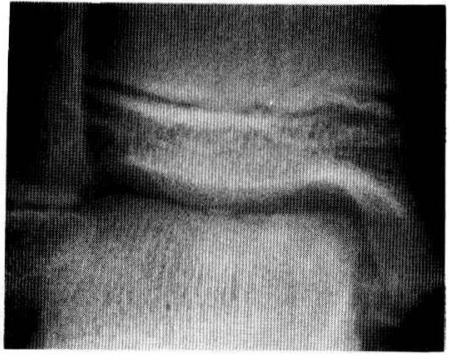

a

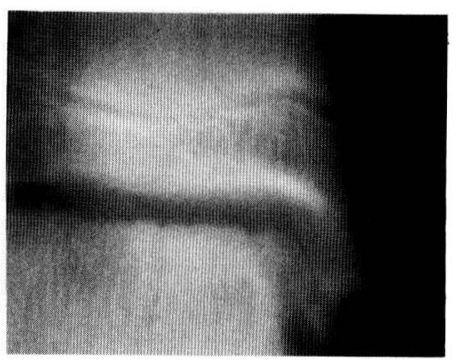

c

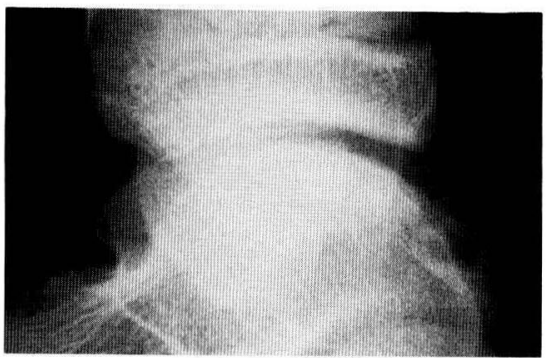

h

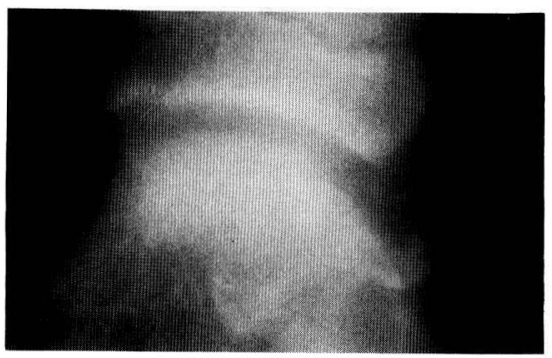

d

図 1 症例 1,12 才，男性 明らかな外傷歴はなく, 階段昇降時の右足関節痛を訴えた. 単純 X 線像 a）b）にて滑車内側の不整と遊離骨片を認めた. 断層 X 線像 c）d）にて，より明膫に病巣部が描出された. 
スト，内反ストレステストが陽性であった。

$\mathrm{X}$ 線所見：単純 $\mathrm{X}$ 線像, 断層撮影にて右距骨滑車外 側に異常像を認めた（図一 4).

勒帯損傷に対して 1 次修復術とGould 法を施行し たが，距骨滑車部には特別な処置を施さずギブス固定 のみを行った。術後 3 週目より部分荷重を開始し， 6
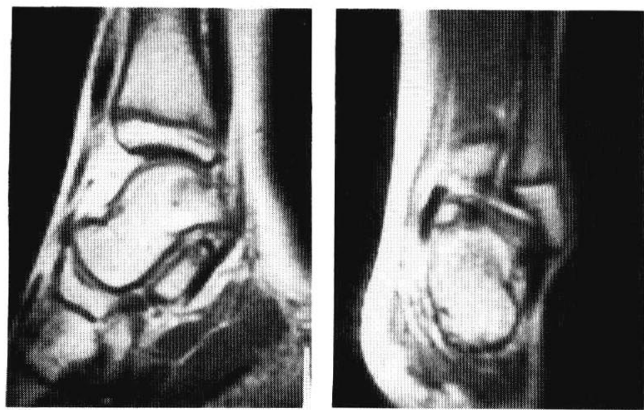

図 2 MRI

MRI にて病巣部は low intensity に描出された。
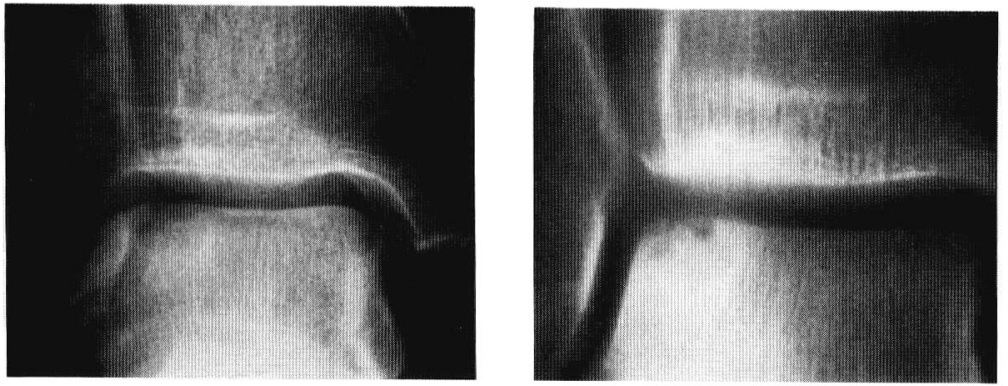

b

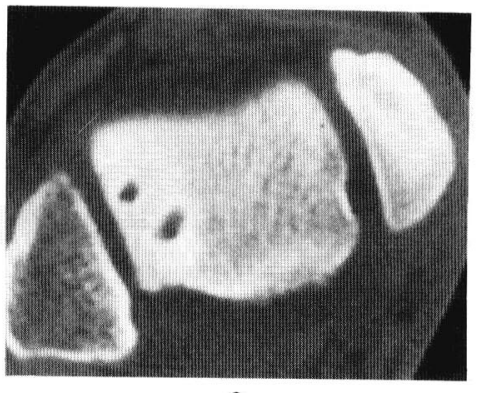

c 現在症状なく，経過観察中である.

症例 $3: 16$ 才, 女性 Berndt 3 型

主訴：両足関節痛 動域制限も認めなかった。 を行ったが，現在のところ症状を認めていない。

\section{考察}

図 3 症例 2,43 才, 男性

週目で内反予防の装具を装着した。その後経過良好て あったが, 術後 8 か月頃より右足関節痛が出現し, 断 層撮影にて Berndt 4 型への進行を認めた (図一 5 ).

2 年前より足関節底屈時の疼痛が出現した. 明らか な外傷歷はない. 初診時, 関節周囲の腫脹はなく, 可

$\mathrm{X}$ 線所見：単純 $\mathrm{X}$ 線像にて両側足関節内側に異常 像を認めた（図－6）. Herbert screwにて固定した。 症例 4, 5, 6 はいずれも外傷歴を認め, 単純 X 線 にて Berndt 4 型であった。治療は 3 例とも骨片摘出

距骨滑車部の骨軟骨損傷に対しては，離断性骨軟骨 炎，骨軟骨骨折，dome fracture など様々な呼称がつ

右足関節捻挫の診断でギブス固定を施行したが，症状不変のため 再受診した. 1 年後の単純 X 線像 a), 断層 X 線像 b) にて滑車外 側の骨透亮像を認めた. CT 像 c)で，より明瞭な骨病巣を認めた。 
けられており，混乱を招く原因となっている.我々は, 明らかな外傷歷の有無により前者を骨軟骨骨折，後者 を離断性骨軟骨炎として区別する様にしている。

(1) 発生部位について

1953 年に Röden $\left.{ }^{8}\right)$ は 55 例の距骨離断性骨軟骨炎を 詳細に検討し, 病巣が距骨の外側にある場合は全例に 外傷歷を認め, 予後も不良であると, 内側型と外側型 の相違を指摘している.

自験例の距骨滑車発生部位を見てみると, 外側型は 中 $1 / 3$ に, 内側型は後 $1 / 3$ に好発して抢り,これは他 の報告と一致していた ${ }^{4110)}($ (図-7).この発生機序に関 し Berndt は, 内側型は足関節内反底屈位で脛骨の外 旋が加わった場合の avulsion type であり, 外側型は 足関節内反背屈位で距骨滑車外側は腓骨に衝突するた めの compression type であると報告している.

(2) 病態, X 線所見について

内側型と外側型の病態， $\mathrm{X}$ 線所見について過去の報 告をもとに比較してみた2)5111) (表 2 )。外傷歴は外側型
表 2 内側型と外側型の相違

\begin{tabular}{|c|c|c|}
\hline & 内 側 型 & 外 側 型 \\
\hline 外傷歴 & $\begin{array}{l}\text { 文献で } 70 \sim 80 \% \text { に認め } \\
\text { た，自験例では } 1 \text { 例もな } \\
\text { かった. }\end{array}$ & $\begin{array}{l}\text { 文献, 自験例でもほほ } \\
100 \% \text { に認めた。 }\end{array}$ \\
\hline X線像 & $\begin{array}{l}\text { 滑車後 } 1 / 3 \text { に好発, 深く } \\
\text { cup 状 }\end{array}$ & $\begin{array}{l}\text { 滑車中 } 1 / 3 \text { に好発, 浅く } \\
\text { wafer 状 }\end{array}$ \\
\hline その他 & $\begin{array}{l}\text { 若い女性で, 外傷歴な } \\
\text { く, 両側例を認める. }\end{array}$ & 予後不良が多い \\
\hline
\end{tabular}

表 3 Berndt の分類と治療方針

\begin{tabular}{|c|c|}
\hline stage 1 & : ১保存的治療 \\
\hline stage 2 & 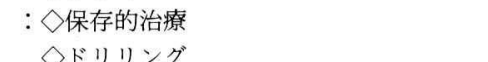 \\
\hline stage 3,4 & $\begin{array}{l}\text { : 仓搔爬, ドリリング, スクリュー固定の } \\
\text { 組み合わせを選択 } \\
\text { ○骨片が小さい症例では, 骨片摘出 }\end{array}$ \\
\hline
\end{tabular}

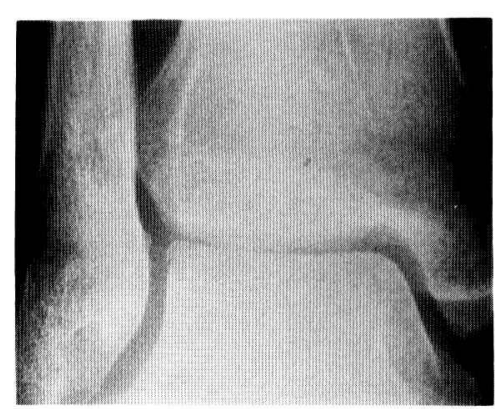

a

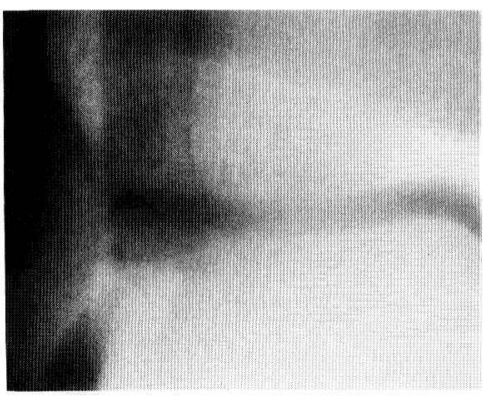

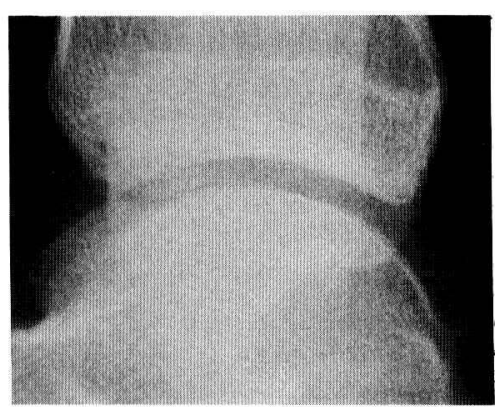

b

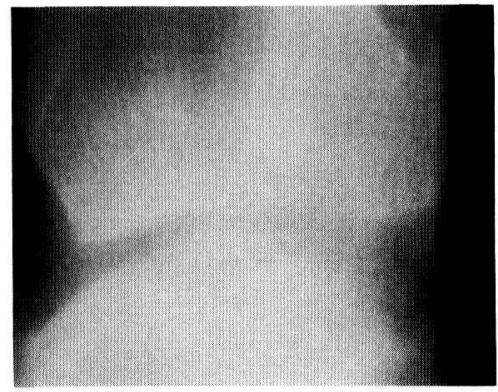

d

図 4 症例 7, 16 才, 女性

初診時単純 X 線像 a) b) と断層 X 線像 c) d）にて滑車外側に骨 病巣を認めた. 前距腓鞄帯損傷に対し 1 次修復術とGould 法を施 行し，骨病巣はギブス固定のみで加療した。 

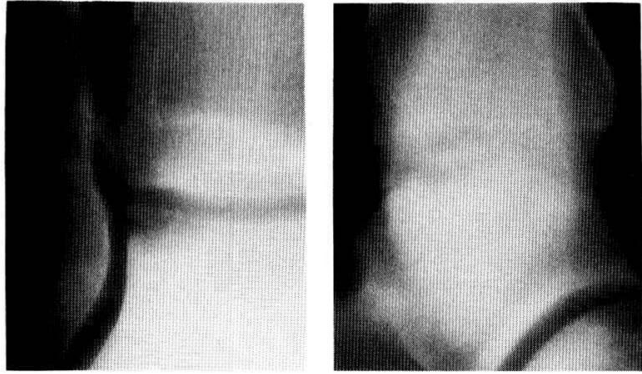

図 5 修復術後 8 か月の断層 X 線像. 骨病巣部の Berndt 4 への進行を認めた.
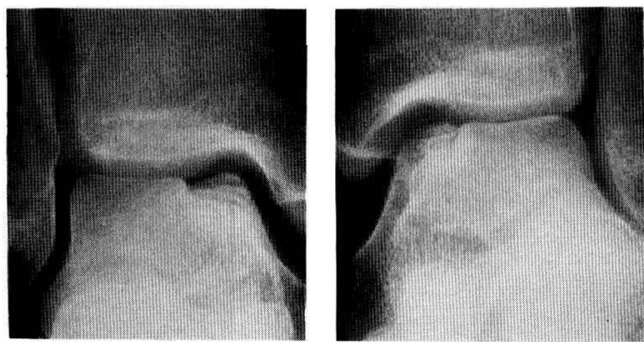

図 6 症例 3,16 才，女性

外傷歷なく, 両側内側に骨病巣を呈していた. Herbert screwにて固定した。

では文献，自験例ともほぼ $100 \%$ 認めたが，内側型で は文献にて 70〜80\%自験例では 1 例も認めなかった。 更に両側発生例には，若い女性で，外傷歷がなく，両 足関節内側に発生するという共通した特徴がある。X 線所見では外側型は距骨滑車中 $1 / 3$ に好発し浅く wafer 状で, 内側型は後 $1 / 3$ に多く深く cup 状であ る。そして外側型は症状が高度で予後不良例が多い. 発生原因には諸説様々であるが，外傷が関与してい ると考えるのが主流である。ただ，外傷の関わり方が 内側型と外側型で異なる様に思われる。すなわち，外 側型では全例に外傷歷を認め，これが主因となるが， 内側型では外傷歷を認めないこともあり局所の循環障 害, 先天的要因などを基盤に慢性ストレスが加わり発 生するのではないかと考えた。

(3) 治療について

治療方針を表一 3 に示す. Berndt の分類で stage 1,2 及び 3 の内側型の症例はまず保存的治療を行い, 無効例と stage 3 の外側型, 及び 4 の症例に対しては 手術的治療を施行している。手術的治療については搔

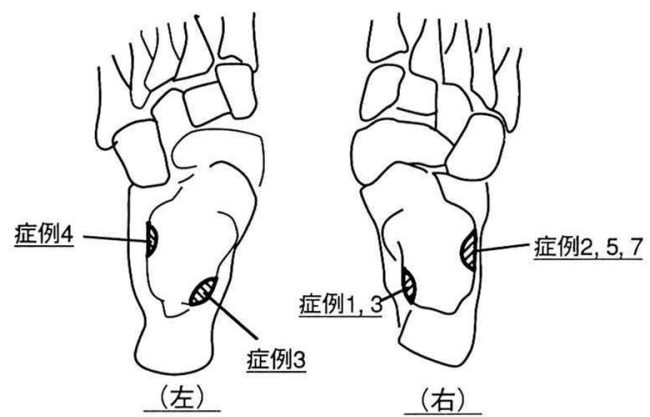

図 7 自験例の発生部位

爬，ドリリング，スクリュー固定，それぞれの組み合 わせを症例に応じて選択している . 原則として骨接 合を考えているが, 不可能なものには骨片摘出を行う. それに, 長期観察した症例での変形性関節症への移行 は膝に比べはるかに低い様である67). ただし，外側型 は症例 7 の様に進行が早いこともあり注意深い治療が 必要と思われた。単純 $\mathrm{X}$ 線像や断層撮影のみでなく,

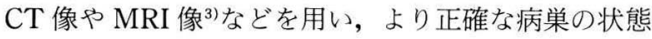
把握をすることが大事であると思われた。

\section{ま と め}

(1) 足関節に発生した 7 例 8 関節の離断性骨軟骨炎 について報告した。

(2) 外側型，内側型には臨床像に相違が見られ，そ の発生要因にも若干の相違があると思われる。また, 外側型は進行が速いので，内側型に比し注意深い治療 が必要であると考えた。

(3) stage を正確に把握するのに, CT や MRI は有 効であると思われた。

\section{文献}

1) Berndt, A. L. et al. : Transchondral fractures of the talus. J. Bone Joint Surg., 41-A : 988-1020, 1959.

2) David, J. S. et al. : Injuries to the talus-neck fractures and osteochondral lesions. The Journal of Foot Surgery, $30: 310-318,1991$.

3) David, W. N. et al. : Osteochondritis dissecans of the talus and neck. Journal of Computer Assisted Tomography, $14: 804-808,1990$.

4）石下俊一郎・他：距骨滑車に生じた離断性骨軟骨炎 の 5 例. 関東整災誌 $16: 207-212,1985$. 
5）川井和夫・他：距骨の骨軟骨骨折. Journal of Joint Surgery, $15:$ 167-178, 1986.

6) Kenneth, A. P. et al. : Osteochondral fractures of the talus. J. Bone Joint Surg., 69-B : 89-92, 1987.

7) Mats, B. et al. : Ostechondritis dissecans of the ankle. J. Bone Joint Surg., : 69-B : 93-96, 1987.

8) Roden, S. et al. : Osyechondritis dessecans and similar lesions of the talus. Acta. Orthop. Scand., 23:
51-66, 1953.

9）高倉義典：距骨離断性骨軟骨炎の治療，関節外科 $11: 133-140,1992$.

10）山下 繴・他：距骨に発生した離断性骨軟骨炎の 4 例. Joint, $12: 138-144,1987$.

11）吉本隆昌・他：距骨の骨軟骨骨折の検討. 整形外科と 災害外科 $38: 869-874,1989$. 